\title{
ABO Blood Group in Patients with Peptic Ulcer Disease: Association with Secretor Status
}

\author{
*M N AKHTAR **A R BUTT *M TAYYIB *T TASNEEM \\ * Pathology department Postgraduate Medical Institute, Lahore. \\ ** South Medical Mayo Hospital, Lahore. \\ (orrespondence to Dr: Muhammad Naveed Akhtar
}

Aims and objective of the study is to find $\mathrm{ABO}$ blood group association with secretor status in peptic ulcer disease patients. ABO blood grouping by direct agglutination test and secretor status by agglutination inhibition test. 50 controls and 50 endoscopically diagnosed PUD patients were selected. Blood group $\mathrm{O}$ is associated with duodenal ulcer but no association with secretor status was found.

Key words: ABO, blood group, secretor, PUD, peptic ulcer disease

The blood groups are genetically determined antigens which are detected on red cell surface by using specific anti-sera. $\mathrm{ABO}$ is the most important blood group system. Individuals of $\mathrm{A}, \mathrm{B}$ and $\mathrm{AB}$ groups contain $\mathrm{A}, \mathrm{B}$, and $\mathrm{AB}$ antigens respectively. People with $A$ and $B$ groups have anti-A and Anti-B antibodies respectively while group $A B$ contains no antibodies. Blood group $\mathrm{O}$ has no antigen but has antibodies against $\mathrm{A}$ and $\mathrm{B}$ antigens. The antigens of $\mathrm{ABO}$ and $\mathrm{Hh}$ groups are synthesized by sequential addition of sugar residue to a common precursor substance by specific glycosyltransferases. The difference in the terminal sugar determines these antigens ${ }^{1,2,3}$. The individuals who secrete the water soluble substances A, B and $H$ called glycoproteins, in saliva and other body fluids like gastric secretions, tears, urine, bile, milk, semen, amniotic fluid and some pathological fluids as well known as "secretors" where as others who lack this property are called non-secretors ${ }^{4.5}$. The antigens expressed on both the red cells and in the secretions are determined by the interaction of $\mathrm{Hh}$, Sese, $\mathrm{ABO}$ and Lele genes ${ }^{1.2 .3}$.

There is an association between $\mathrm{ABO}$ blood groups and certain diseases. The strongest relationship is between duodenal ulceration and blood group $\mathrm{O}^{\circ}$. Over $90 \%$ of duodenal ulcer patients and $70 \%$ gastric ulcer patients are infected with Helicobacter Pylori (HP) ${ }^{7}$. The present study was carried out to find out the association of $\mathrm{ABO}$ blood groups in peptic ulcer disease with secretor status.

\section{Materials and methods}

Fifty endoscopically diagnosed peptic ulcer patients were selected from medical units of Services Hospital, Sir Ganga Ram Hospital, and Mayo Hospital. Another 50 individuals from blood bank were taken as a control. ABO blood grouping was done on blood samples of patients and controls. One ml non-stimulated saliva was used for $\mathrm{ABH}$ secretor status analysis by Wiener agglutination inhibition test ${ }^{5}$. Both forward and reverse grouping were done by slide and tube methods described by Dacie and Lewis ${ }^{8}$. Potent anti-A, anti-B and control A, B and O Cells were used for grouping. Statistical analysis of Chi square test and "p" value were used to analyze the results and data in the present study.

\section{Results}

The ABO blood group observed in controls were $\mathrm{B}=36 \%$, $\mathrm{O}=34 \%, \mathrm{~A}=22$ and $\mathrm{AB} 8 \%$ and peptic ulcer disease patients these were $A=12 \%, B=26, O=58 \%$ and $A B 4 \%$. The results are shown in table 1 . The blood group $O$ patients with duodenal ulcer were more as compared to other groups $\left(\chi^{2}=8.23\right.$ with $\left.1 \mathrm{df}, \mathrm{p}=0.005\right)$. Thus there is association between duodenal ulcer and blood group $\mathrm{O}$.

Table 1 ABO Blood Group Distribution in Controls and PUD

\begin{tabular}{lll}
\hline Blood Group & PUD\% & Controls $\%$ \\
\hline A & 12 & 22 \\
B & 26 & 36 \\
O & 58 & 34 \\
AB & 04 & 08 \\
Total & 100 & 100 \\
\hline
\end{tabular}

Sex distribution of $\mathrm{ABO}$ Blood groups in Controls and PUD is shown in table 2. No association was found between duodenal ulcer and gender with reference to blood groups $\left(\chi^{2}=0.201\right.$ with $\left.1 \mathrm{df}, \mathrm{p}>0.5\right)$.

Table 2 Frequency of $\mathrm{ABO}$ blood groups in male and female Controls and PUD patients

\begin{tabular}{lllll}
\hline \multirow{2}{*}{$\begin{array}{l}\text { Blood } \\
\text { group }\end{array}$} & \multicolumn{2}{c}{ Male } & \multicolumn{2}{c}{ Females } \\
\cline { 2 - 5 } & Control ) & PUD & Control & PUD \\
\hline A & $6(17 . .7 \%)$ & $4(11.8 \%)$ & $5(31.3 \%)$ & $2(12.4 \%)$ \\
B & $13(38.2 \%)$ & $8(23.5 \%)$ & $5(31.3 \%)$ & $5(31.3 \%)$ \\
O & $13(38.2 \%)$ & $20(58.8 \%)$ & $4(25 \%)$ & $9(56.3 \%)$ \\
AB & $2(5.9 \%)$ & $2(5.9 \%)$ & $2(12.4 \%)$ & 0 \\
Total & $34(100 \%)$ & $34(100 \%)$ & $16(100 \%)$ & $16(100 \%)$ \\
\hline
\end{tabular}

The distribution of secretor status among control group and peptic ulcer disease patients was determined and the results are given in table 3 and table 4 . When duodenal ulcer male and female patients were compared for association with secretor status, no association was found between any sex and secretor status. $\left(\chi^{2}=0.5829\right.$ with $1 \mathrm{df}$, $\mathrm{p}>0.5)$.

Table 3 Secretor Status.

\begin{tabular}{lll}
\hline Secretors status & PUD\% & Controls $\%$ \\
\hline Secretor & 76 & 80 \\
Non-secretor & 24 & 20 \\
\hline
\end{tabular}


Table 4 Frequency of male and female secretor status in PUD patients and controls

\begin{tabular}{|c|c|c|c|c|}
\hline \multirow{2}{*}{$\begin{array}{l}\text { Blood } \\
\text { group }\end{array}$} & \multicolumn{2}{|c|}{ PUD } & \multicolumn{2}{|c|}{ Control. } \\
\hline & Male & Female & Male & Female \\
\hline Sector & $27(79.4 \%)$ & $11(68.7 \%)$ & $28(82.4 \%)$ & $12(75 \%)$ \\
\hline $\begin{array}{l}\text { Non } \\
\text { Sector }\end{array}$ & $7(20.6 \%)$ & $5(31.25 \%)$ & $6(17.6 \%)$ & $4(25 \%)$ \\
\hline Total & $34(100 \%)$ & $16(100 \%)$ & $34(100 \%)$ & $16(100 \%)$ \\
\hline
\end{tabular}

\section{Discussion}

It was found that in peptic uicer patients group $A=12 \%, B$ $=26 \%, \mathrm{O}=58 \%$ and $\mathrm{AB}=4 \%$ showing predominance of blood group O. Among them $40 \%$ were with blood group $O$ who had duodenal ulcer. Similarly results were noticed in various other studies ${ }^{9 \cdot 10.11}$. It was found in peptic ulcer patients that $76 \%$ were secretors with rest of $24 \%$ nonsecretors (table 3 ). Among males $56 \%$ were secretors and $14 \%$ were found to be non-secretors. On the other hand $24 \%$ females were secretor and $10 \%$ were non-secretors in peptic ulcer patients.

In a study carried out in Rawalpindi/ slamabad showed that secretors and non-secretors were $85.3 \%$ and $14.7 \%$ respectively. The male secretors were $81.6 \%$ as compared to $90.9 \%$ of the female secretors. Hook-Nikanne et al ${ }^{12}$ found $80 \%$ of blood donors as secretor and $20 \%$ as non-secretors in Helsinki urban population. Lamey et al ${ }^{13}$ (1994) found secretor as $64 \%$ and non-secretors as $36 \%$ in Sri-Lankan population.

Since the identification of blood groups in man, a relationship between different blood groups and certain diseases has been established. Blood group antigens are considered receptor as well as protective for microbial agents ${ }^{14,15}$. Bacterial colonization and ensuing inflammatory response may be influenced by the host expression of $\mathrm{ABO}$ blood group antigens ${ }^{16}$. Helicobacter pylori colonization and ensuing inflammatory response is more in blood group $O$ patients ${ }^{17}$. There is a close correlation between H. Pylori and peptic ulcer ${ }^{18}$. Mentis et $\mathrm{al}^{11}$ found similar findings where blood group $\mathrm{O}$ was overrepresented among peptic ulcer patients. Non-secretors were predominating. The association with non-secretor status is not well defined.

The association between duodenal ulcer and different blood groups has been known for more than 40 years. Individuals with blood group $\mathrm{O}$ have a $30-40 \%$ higher incidence of duodenal ulcer than those of the remaining blood groups ${ }^{9.10}$. The adherence to the gastric epithelial cell is mediated by fucosylated blood group antigens associated with blood group $\mathrm{O}$ phenotype suggesting that it might explain the higher prevalence of peptic ulceration in individuals with blood group $\mathrm{O}^{19}$. The blood group $\mathrm{O}$ association is particularly evident with ulcers of the antrum and prepylorus. These are exactly the same parts of the stomach as where H. Pylori is most frequently found ${ }^{12}$.
Alkout et $\mathrm{al}^{17}$ suggested that $\mathrm{H}$ type 2 , found on almost all individuals in a key receptors of $\mathrm{H}$ pylori and that the increase susceptibility of group $\mathrm{O}$ to peptic ulcer disease might be partly caused by higher density of colonization by these bacteria compared with other blood groups. High levels of inflammatory mediators in blood group $\mathrm{O}$ individuals might contribute to tissue damage leading to ulceration ${ }^{20}$. Fucose is the immunodominent sugar of the $\mathrm{H}$ antigen of blood group $\mathrm{O}$. Adhesins of $\mathrm{H}$. pylori that bind fucose have been identified ${ }^{21}$. Non-secretor status is not related to $\mathrm{H}$. Pylori infection but is independently associated with endoscopic gastroduodenal disease $^{22}$.

Other workers failed to define any association between infection $\mathrm{H}$ pylori and blood group or secretor status ${ }^{12.23 .24}$. Predisposition to $\mathrm{H}$. pylori gastric antral infection is not associated with any $\mathrm{ABO}$ and secretor status $^{27}$. Further carefully controlled studies are needed to find relationship between $\mathrm{H}$. pylori, peptic ulcer disease and blood group antigens which may reveal the basis of this association. It is quite challenging that after so many years of study the basis of these associations between blood group antigens and duodenal ulcer remain unknown

\section{References}

1- Watkins WM. The ABO blood group system: historical background. Transfusion Medicine 2001: 11: 243-265.

2- Mollison PL, Engelfriet CP, Contreras M (cd). ABO, Lewis, $\mathrm{Ii}$ and $\mathrm{P}$ groups. In: Blood transfusion in clinical medicine. $9^{\text {th }}$ edition Oxford: Blackwell Scientific Publications 1993:149-203.

3- Schroeder ML. Red cell, platelet and white cell antigens. In: Lee GR, Foerster J, Lukens J, Vas FP, Green JP, Rodgers GM (ed.) Wintrobes Clinical Haematology. $10^{\text {th }} \mathrm{Ed}$ Philadelphia: Lippincott Williums and Wilkins 1998: 776779.

4- Rizvi SiMA, Zuberi SJ. Secretor status as a genetic marker in duodenal ulcer - A comparative study. JPMA 1992; 42(10): 243-44.

5- Vidas I, Delajlija M, Vuksan BT, Marvak MS, Cindric N and Maricic D. Examining Secretor Status in the saliva of patients with oral pre-cancerous lesions. J oral Rehabl 1999; 26(2): 177-82.

6- Bhatti R, Sheikh DM. Variations of ABO blood groups, gene frequencies in the population of Sindh (Pakistan). Annals 1999; 5(3-4): 328-331.

7- Palmer KR, Penmar ID. Disease of the Alimentary Tract and Pancreas, Peptic ulcer disease. In: Haslett C, Chclner ER, Hunter JAA, Boon NA (Ed). Davidson, s Principles and Practices of Medicine. $18^{\text {th }}$.edn: Churchill Livingstone, 1999: 631-38.

8- Dacie JV and Lewis SM, Waters AH et al. Laboratory aspects of blood transfusion. In: Dacie JV, Lewis SM (Ed). Practical Haematology $7^{\text {th }}$ edn: Churchill Livingstone 1995: 455-476.

9- Aird I, Bentall HH, Mehigan JA, Roberts JAF. The blood groups in relation to peptic ulceration and carcinoma of colon, rectum, breast and bronchus. BMJ 1954; 2; 315-321. 
10- Clarke CA, Edwards JW, Haddock DRW, Evans AWH, McConnell RB, Sheppard PM. ABO groups and secretor character in duodenal ulcer. BMJ 1956; 2; 725-731.

11- Mentis A, Blackwell CC, Weir DM, Spiliadis C, Dailianas A, Skandalis N. ABO blood group, secretor status and detection of Helicobacter pylori among patients with gastric or duodenal ulcers. Epidemiol infect 1991; 106:221-229.

12- Hook-Nikanne J, Sistonen P, Kosunen TU. Effect of ABO blood group and secretor status on the frequency of Helicobacter pylori antibodies. Scand J Gastroentral 1990; 25: $815-818$

13- Lamey PJ, Douglas PS, Napier SS. Secretor status and oral cancer. Br J Oral Maxillofac Surg 1994; 32: 214-17.

14- Niemierko ML. Topley N, Smith C, Jones KV, William ID. $P_{1}$ blood group phenotype, secretor status in the patients with urinary tract infections. Clinical Nephrology 1995; 44(6): 376-81.

15- Burford Mason AP, Willoughby JMT, Weber JCP. Association between gastrointestinal tract carriage of candida, blood group $\mathrm{O}$, and non-secretion of Blood group antigens in patients with peptic ulcer. Dig Dis Sci 1993; 38 (8): 1453-58.

16- Heneghan MA, Moran AP, Feeley KM et al. Effect of host Lewis and $\mathrm{ABO}$ blood group antigen expression on Helicobacter Pylori colonisation density and consequent inflammatory response. FEMS Immunol Med Microbiol 1998; 20:257-266.

17- Alkout AM, Blackwell CC, Weir DM et al. Isolation of a cell surface component of Helicobacter pylori that binds $\mathrm{H}$ type 2, Lewis (a), Lewis (b) antigens. Gastroenterology 1997; 112(4): 1179-87.

18- Vaira D, Miglioli M, Mule P et al. Prevalence of peptic ulcer in Helicobacter Pylori positive blood donors. Gut 1994; 35:309-12.

19- Hein HO, Suadicani P, Gyntelberg F. Genetic markers for peptic ulcer .A study of 3387 men aged 54 to 74 years; the Copenhagen male study. Scand J Gastroenterol 1997; 32: 16-21.

20- Alkout AM, Blackwell CC, Weir DM. Increased inflammatory response of person of blood group $\mathrm{O}$ to Helicobacter pylori. J Inf Dis 2000; 181; 1364-69.

21- Boren T, Falk P, Roth KA, Larson G, Nomark S. Attachment of Helicobacter pylori to human gastric epithelium mediated by blood group antigens. Science 1993; $262 ; 1892-1895$.

22- Dickey W, Collins JSA, Watson RGP, Sloan JM, Porter KG. Secretor Status and Helicobacter pylori infections are independent risk factor for gastroduodenal disease. Gut 1993; 34: 351-353.

23- Chesner IM, Nicholson G, Ala F, Elliott TSJ, Langman MJS. Predisposition to gastric antral infection by Helicobacter pylori: an investigation of any asasociation with $\mathrm{ABO}$ or Lewis blood group and secretor status. Eur $\mathrm{J}$ Gastroenterol Hepatol 1992: 4: 377-379.

24- Umlauft F, Keefe EB, Offner F et al. Helicobactor Pylori infection and blood group antigens: lack of clinical association. Am J Gastroenterol 1996; 91(10): 2135-8. 